\title{
MANAGEMENT OF MOVEMENT OF VISITORS IN A SPORTS FACILITY
}

\author{
Duško Kuzović \\ Eastern Mediterranean University, Department of Architecture, Cyprus
}

\begin{abstract}
Management of movement of visitors in a facility is essential for a successful organization of a sports event. From a visitor's entrance into the premises of the sports facility to its place on the stands, corridors have to be defined. Depending on its position, a corridor is additionally divided into logical zones: a zone between a border of the plot and the facility, an outer zone, an internal zone, a zone of seats or stands. Precise specification of needs within a zone is used to organize movement of visitors safely and efficiently. Communications can be horizontal and vertical. Each group has set rules for design and maintenance. Depending on the applied technical solution, entrances have a defined capacity that must be taken into account when a sporting event is organized. Besides the entrance for visitors, there are many entrances dedicated to specific groups such as competitors, VIP, security, service, medical assistance, media, persons with special needs, etc. Management of movement of users in a facility must be a subject of careful analysis because it is of a great importance for the general impression on the quality of a sports facility.
\end{abstract}

Key words: ENTRANCES / CORRIDORS / SAFETY OF MOVEMENT / MANAGEMENT OF MOVEMENT

\section{INTRODUCTION}

Management of movement of visitors in a facility is essential for a successful organization of a sporting event. Due to successful organization of movement from the entrance into the premises of a sporting facility to the seats or stands for visitors, precisely shaped corridors must be defined. Zoning is also of a great importance because the needs of users change depending on the characteristic zone of a corridor in which it is located. Because of that, depending on the position in relation to the entrance and the stands, corridors can be additionally divided into the logical sequence: the zone between the borders of the plot and the facility, the outer zone, the internal zone, the visitors' zone - zone of the stands. It is simple to organize safe and efficient movement from and to the place on the stands by a precise division of characteristic zones of movement of visitors and specifications of needs within the zone (Mitrović, 1983; Ilić, 1998).
Communication and entrances into the facility are equally important places for visitors on their way to their place on the stands. Management of movement of users in the facility has to be a subject of everyday analysis and careful maintenance bearing in mind the importance of efficient movement of users for the overall impression of the sports facility quality. (Department for Culture, Media and Sport, 2008)

The aim of this paper was to specify and analyse movement of users from the entrance into the premises of the facility to their places on the stands, defining elements of the corridor, analysis of certain zones within the corridor, specification of conditions for designing and maintaining the lines of movement in a sports facility. It can be expected that the paper will contribute to better understanding of the question of designing and maintaining lines of movement of visitors in a sports facility, and thus better maintaining of movement of visitors. 


\section{MOVEMENT OF VISITORS IN A FA- CILITY}

Two basic principles to manage movement of visitors in a sports facility can be defined through the need for security and convenience in movement (Geraint, Sheard, \& Vickery, 2007; UEFA, 2011a; FIFA, 20116).

\section{Safety}

The concept of safety can be understood as a need to avoid the occurrence of panic, security from vandalism, disorderly conduct, injuries, fires, terrorist attacks, any kind of accident, etc. The design of the sports facility should be such as to prevent all the above consequences (FIFA, 2004; OECD, 2011).

\section{Convenience in movement}

This term implies simplicity, lightness, movement without excessive physical and mental exertion, the absence of a sense of being lost, with clear directions. In doing so, all elements of the facility used to help the movement of visitors, such as ramps, stairs and elevators, must meet all requirements stipulated by regulations.

\section{ZONING OF A SPORTS FACILITY}

According to the type of the event, the whole sports facility can be divided into several zones:

1. Zone of the field of play,

2. Zone of the auditorium,

3. Zone of internal communication,

4. Zone of external communication,

5. Zone between the sports facility and the limits of the premises.

The aforementioned zones exist both in small and in large sports facilities. Each of these zones are further divided into subsections that have originated as a requirement imposed in practice. For example, the audience is divided according to zones reserved for the fans of the two sports clubs, or within the said zones according to the different categories of the seating. In practice, partition walls between individual zones are elements such as fences, walls, or denivelation (Ortner, 1956; Geraint, Sheard, \& Vickery, 2007; Russ, 2009).

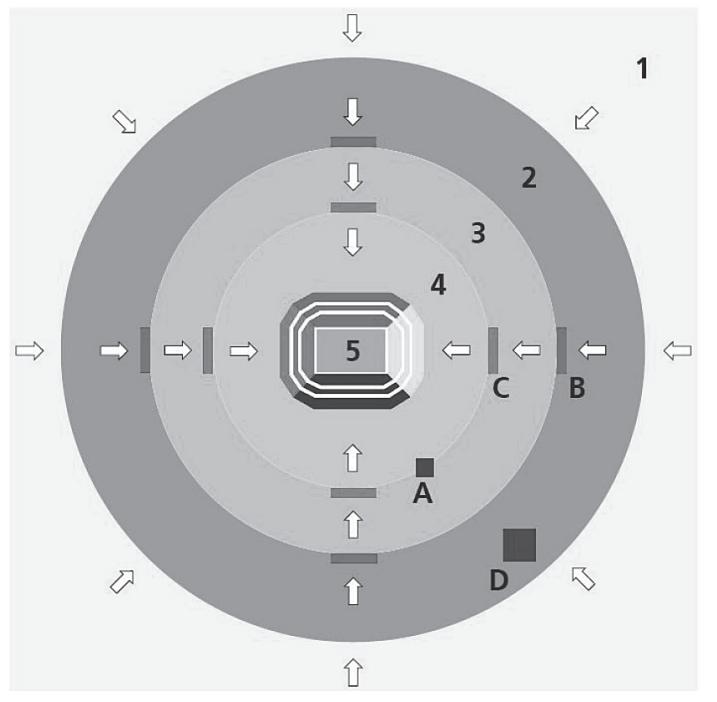

Picture 1 Zones of a football stadium during a FIFA event: 1. The public zone, 2. The exclusive zone of the sports facility, 3. Outer perimeter (visual ticket check), 4. Inner perimeter (electronic access control), 5. The stands. A. Ticketing clearing point; B. Mags and bags; C. Turnstiles; D. Stadium ticketing centre (adjusted to FIFA 2011a).

\section{ENTRANCES INTO A SPORTS FACIL- ITY}

Entrances into the sports facility are arranged according to users' needs so that they go from the entrance into the facility towards their destination in the safest and the most efficient way. Entrances can be grouped according to the type of user as follows:

1. Entrances into the stands,

2. Entrances into VIP areas,

3. Entrances into service rooms,

4. Entrances for players,

5. Entrances for the security and the police,

6. Entrances for medical help,

7. Extra entrances for needs of evacuation from the stadium in the case of accident.

All entrances should be used simultaneously either for entering the stadium or for the exit; mixed use is not recommended. All services next to entrances must be at a safe distance from the entrance. It is usually assumed that one open gate can be safely used by up to 4000 visitors per hour, or by 500 to 750 visitors if there are turnstiles (UEFA, 2011a; UEFA, 2011b; UEFA, 2011c).

\section{Location of an entrance in relation to the fa-} cility

The entrance must be in line with internal and external communications. At the same time, the space 
in front of and behind the entrance must meet several conditions. Entrances must be arranged at such distance as to avoid crowding; there should be separate entrances for fans of the rival team, while close entrances can be grouped for easier management of groups of visitors, but only if they are used for the same fan groups or the same type of users. Private entrances are designed for players, VIP visitors, managers, sponsors and the media, and they should be located near the parking lot reserved for them. Also, it is necessary to design entrances that can be used for the needs of persons with special needs (with disability, visually impaired, in a wheelchair, etc.). Emergency exits are located in the perimeter fence and can be opened only in exceptional cases. Evacuation exits are there to empty the sports facility in a few minutes, although several hours may be needed for it to be filled. The recommended minimum width of the entrance is $120 \mathrm{~cm}$ (Gallant, 2008; Geraint, Sheard, \& Vickery, 2007; UEFA, 20116).

\section{Control of the entrance}

From the entrance into the sports facility to the place on the stand, the user has to pass one or several check points. The aim of these checks is ticket control, but also other types of control aimed at the safety of users. The first control is at the very entrance and it implies security control together with the ticket control. The second control is less formal and is mostly dedicated to safety measures. The third control has the security functions and is done on places where special groups of spectators are separated. At each of the listed places there has to be sufficient room provided to avoid obstructions and crowding; bars and restaurants must be located at a safe distance.

\section{Transparency and simplicity of the direction of movement}

Because of moving in a group during entering and exit, it is essential for information about directions of movement to be transparent. It is necessary to make spectators safe by regular and clear signalling especially in large sports facilities. Therefore several solutions should be implemented:

a) A number of choices a spectator is faced with on his way to his seat should always be as small as possible (two are recommended),

b) All signs and marks must be visible from the most unfavourable parts of the corridor,

c) Signs must be clear and readable.

Visitors must have two directions to choose from at the most (one of which is the right one). If a spectator is moving in a crowd which is moving fast, and the spectator is under pressure, the number of decisions he can make is reduced, and time needed to choose is prolonged. In addition to visual signs, it is necessary to organize the assistance service. (Smith, 1996; UEFA, 20116; Geraint, Sheard, \& Vickery, 2007; FIFA, 20116)

The direction of movement of visitors to the security zone

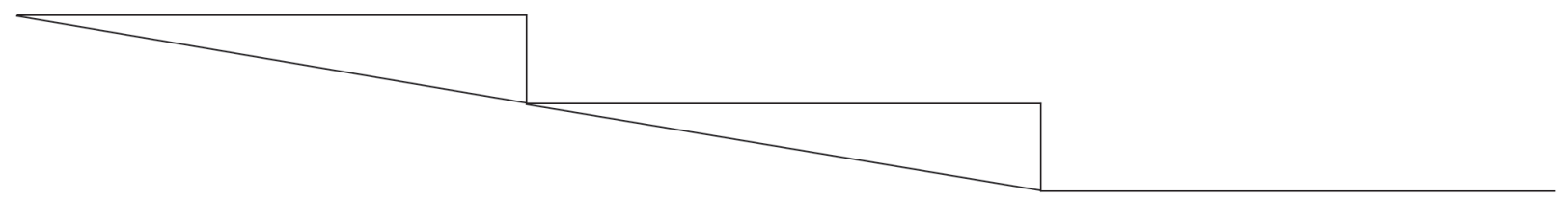

The direction of movement of visitors to the security zone

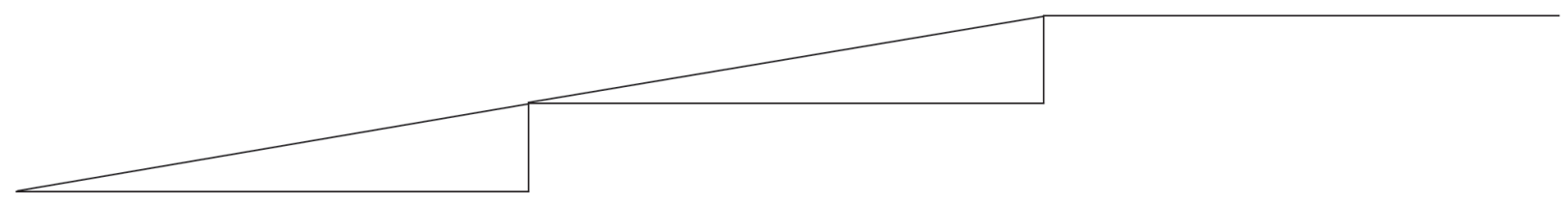

Picture 2 Triangular surfaces formed sidewise for a temporary stop for visitors to think about further movement without blocking the flow of the crowd on the corridor (adapted from Geraint, Sheard, \& Vickery, 2007) 


\section{Behaviour of visitors from the entrance to the seat}

Conducted studies have defined the main dilemmas and questions a spectator asks on his way from the entrance in the facility to his seat. Signs and instructions in the sports facility have to answer the questions in the most efficient way. Common spectators' questions are: (Gallant, 2008)

1. Am I the fan of the home or of the visiting team?

2. Do I have a ticket for standing or sitting?

3. Do I have a seat in the upper or a lower zone?

4. Am I in the blue or red section?

5. Is my seat number from 1 to 10 or from 11 to 20 ?

6. Where is my seat in this part of the row?

\section{Clear visibility}

In a sports facility, transparency and clearness of information are the first and foremost task. There is no space in the corridor for dramatic games of light and darkness, familiar and unknown that are used in other areas of architecture. All collimation lines along the corridor where spectators are moving must be clear and long to enable easy and quick orientation. Clear visibility is especially important in case of an accident when a spectator is in a group, forced to go along with the others and with reduced concentration. Changes of level must be carefully designed and planned in order not to provoke crowding in front of stairways.

\section{Clear sign system}

Sign system is not only a passive system of signs placed to decorate the facility or to surround the building. Its primary role is to answer questions that the spectator may ask to reach his place among the seats as soon as possible and in a simple way. At the same time, we should pay attention to a line of elements that help a person identify the place of the message, comprehend what there is in that particular message, understand it and decide whether to use it or not. Understanding the human sight, field of vision, primary colour of the board with the sign, colour of the sign, font type and size, contrast of the board in relation of the surface, light - all these elements can be helpful in making the decision. This is a job for highly specialized professionals.

\section{Safe areas in the corridor}

Areas by the lanes of the route are there for visitors to stop there without preventing the main group to continue moving.

\section{Hospitality lounges}

It is recommended that kiosks, bars, cafés, day care centres for children must be at least 6 meters away from the exit or the entrance into the Zone of the sports facility in which they are located (Rick, Langston, \& de Valence, 2003; McGregor \& Shiem-Shin, 2003).

\section{EXIT OF VISITORS FROM THE FA- CILITY}

It is recommended that the exit route from the facility follows the route of the entrance. All recommendations for determination and position of entrances into the facility remain the same for the route towards the exit from the facility. Everything the visitor does while entering the facility remains the same at the exit. He repeats the questions asked from the entrance to his seat are, but in the reverse order.

Two types of exits from the facility are needed: regular and emergency. It is not necessary to visually explain the regular exit. The emergency exit is used in the case of an accident and it must be completed in the defined time frame. In both exits it is always necessary to analyse time needed for exit of visitors from the facility. According to studies and experience, if there are no obstructions during movement, in 60 seconds a spectator can cross $150 \mathrm{~m}$ on the flat or slightly inclined field, or $30 \mathrm{~m}$ on the stairway. The distance between people is $2.5 \mathrm{~m}$ on the flat terrain, or $0.75 \mathrm{~m}$ on the stairway.

\section{RECOMMENDATIONS FOR SHAP- ING CORRIDORS FOR MOVEMENT OF VISITORS}

\section{Gates and turnstiles}

Gates are the most inexpensive and the fastest solution for enters into the facility. About $4000 \mathrm{spec}-$ tators can go through it per hour. Their disadvantage is that they are insufficiently sophisticated for security checks.

Turnstiles are better safety solution, but their entry capacity is from 500 to 750 visitors per hour. Experiences from practice show that the real average number of spectators that can safely go through this type of gate is 660 per hour. If the stands have to be filled for a shorter time, it is necessary to provide a larger number of such entrances. 
Entrances to the stands can have a system that records the number of visitors which helps security in the sports facility. Ticket control is more precise because if the tickets are coded and issued in the specific name, all present in the sports facility can be easily identified by computer, and thus discourages uncontrolled intrusion into the venue. Also, because of preventing crowding of visitors in front of the entrance, sales of the tickets should be at least 10 meters away from the entrance.

Disadvantages of such entrances are problems with maintaining hygiene of floor under the gate and the possibility of injuring spectators in the case of uncontrolled access. Crowd control retracting belt stanchions and barriers are usually placed at the entrance of the facility to provide control at the entrance.

\section{Horizontal movement in the corridor}

Entering the sports facility before the event may last up to three hours, while the exit from the facility has to be completed within several dozen minutes. Therefore, "crowd pipeline" leading from the entrance to the passage towards seats and back should be defined and analysed in detail. (UEFA, 2011a,b,c)

Proper estimation of movement of users through the sports facility is very important for the design and control of corridors. It is essentially based on several elements:

1. Entrances. Width and type of entrances determine the number of visitors that can enter the facility in the unit of time. The desired period of filling and emptying the facility determine the number of entrances.

2. Exits. Doors must open in the direction of movement of visitors, i.e. outside. They can accept 40 to 60 visitors per minute in the unit of width $(60 \mathrm{~cm})$. Such experience shall determine the number of exits in relation to the desired time.

3. Corridors and passages. Their width is defined by regulation and they are changed during time.

4. Areas of individual obstruction. These are additional surfaces to existing corridors for movement, and they are for visitors to take a rest without preventing others from moving through the corridor.

\section{Vertical movement in the corridor}

This type of movement (stairs and ramps) is necessary, but it has to be used as little as possible. The speed of movement of a group on vertical routes is considerably smaller than in horizontal movement, and obstructions happen more often.

Stairs are the compact solution, but also a bigger source of danger than steep ramps. It is recommended that they are designed in pairs, with the biggest allowed inclination of $33^{\circ}$. At determining inclination, the most important role plays the relationship of height and width of stairs. Handgrips and the surface of stairs are very important because they have to prevent slipping and to be easy to maintenance as well.

Steep (inclined) ramps have the advantage of being simpler for movement than stairs, and the consequences of an injury are less dangerous than in case of a fall from stairs. If they are designed and constructed to have an adequate width and if the construction can support it, they can be used for vehicles as well. Their form can be circular or rectilinear. Handrails and finishing must be in line with the usage.

Escalators. Because of high price and costs of usage, they are rarely used in sports facilities.

Lifts. Individually, they are of small capacity and can be a source of danger in case of losing control over movement of visitors. In practice, they are used by VIP, for private use, by members of clubs or executives, but also by security, police, medical teams, media, persons with special needs etc.

\section{CONCLUSION}

Management of movement of visitors in a facility is of a great importance for a successful organization of a sporting event. The corridors must be defined from the entrance into the premises of the sports facility to the visitor's place on the stand. Depending on the position of a characteristic zone of a corridor, there is a logical line: the zone between the border of the plot and the facility, outer zone, inner zone, the zone of the stand. With a precise division of characteristic zones of movement of visitors and specification of needs within a zone, it is easy to organize safe and efficient movement towards and from the stands. According to inclination of the surface, communications can be grouped into horizontal and vertical. Each of the two listed groups has defined rules of design and maintenance. Entrances of the facility are equally important places on the way of a visitor toward the place on the stand. Depending on the technical solution that has been implemented, they have a defined capacity and it has to be taken into account 
while designing the facility, but also while organizing the sports event. Together with the entrance for visitors, there are several entrances intended for specific groups in the facility, such as entrances for players, VIP, security, service, medical help, persons with spe-

\section{REFERENCES}

1. Department for Culture, Media and Sport (2008). Guide to Safety at Sports Grounds. London.

2. FIFA (2004). Safety Regulations. Zurich.

3. FIFA (2011a). FIFA Stadium Safety and Security Regulations. Zurich.

4. FIFA (2011b). Football Stadiums, Technical Recommendations and Requirements. Zurich.

5. Gallant, B. (2008). The facility manager's guide to environmental health and safety. Lanham: Government Institutes.

6. Geraint, J., Sheard, R., \& Vickery, B. (2007). STADIA: A Design and Development Guide. Oxford: Elsevier.

7. Ilić, S. (1998). Sportski objekti [Sports facilities. In Serbian]. Beograd: SIA

8. McGregor, W., \& Shiem-shin Then, D. (2003) Facilities Management and the Business of Space. Oxford: Butterworth-Heinemann.

9. Mitrović, M. (1983). Sportski objekti, sadržaj $i$ obeležja igre i sporta u stambenoj sredini i naselju cial needs, media, etc. Management of movement of users in the facility must be the subject of everyday analysis and careful maintenance bearing in mind the importance of efficiency of movement for a general impression of the quality of a sports facility.
[Sports facilities, The content and features games and sports in the middle of a residential and resort. In Serbian]. Beograd: Arhitektonski fakultet.

10. OECD (2011). Preventing and Reducing Armed Violence in Urban Areas: Programming Note, Conflict and Fragility. OECD Publishing.

11. Ortner, R. (1956). Sportbauten, Anlage-Bau-Ausstatug. München: Calwey.

12. Rick, B., Langston, C., \& de Valence, G. (2003). Workplace strategies and facilities management. New York: Taylor \& Francis.

13. Russ, T. (2009) Site Planning and Design Handbook, McGraw-Hill.

14. Smith, M., (1996). Interiors Management: A Guide for Facility Managers, The Fairmont Press.

15. UEFA (2011a). Access For All, Genève.

16. UEFA (2011b). UEFA Guide To Quality Stadiums, Genève.

17. UEFA (2011v). UEFA Stadium Infrastructure Regulations, Genève.

\title{
MANAGEMENT DER BEWEGUNG VON BESUCHERN IN SPORTOBJEKTEN
}

\begin{abstract}
Zusammenfassung
Das Management der Bewegung von Besuchern in einem Objekt ist von großer Bedeutung für die erfolgreiche Organisierung eines Sportevents. Vom Eintritt der des Besuchers auf die Parzelle des Sportobjekts bis zu seinem Platz auf den Tribünen müssen die Korridore definiert sein. In Abhängigkeit von der Position wird der Korridor zusätzlich in logische Zonen eingeteilt: Zone zwischen der Grenze der Parzelle und des Objekts, äußere Zone, innere Zone, Zuschauerzone. Durch präzise Spezifizierung der Bedürfnisse innerhalb einer Zone wird auf einfache Weise eine sichere und effiziente Bewegung der Besucher organisiert. Die Kommunikationen können horizontal und vertikal sein. Jede der Gruppen hat vorgeschriebene Regeln für Gestaltung und Instandhaltung. In Abhängigkeit von der angewendeten technischen Lösung haben die Eingänge eine definierte Kapazität und dies muss bei der Organisierung eines Sportevents beachtet werden. Neben den Besuchereingängen gibt es noch eine große Anzahl an Eingängen, die für spezifische Gruppen bestimmt sind, wie zum Wetteiferer, VIP, Sicherheitsdienst, Service, ärztliche Hilfe, Medien, Personen mit besonderen Bedürfnissen usw. Das Management der Bewegung von Besuchern in einem Objekt muss Gegenstand einer sorgfältigen Analyse sein, weil es eine große Bedeutung für den allgemeinen Eindruck über die Qualität eines Sportobjekts trägt.
\end{abstract}

Schlüsselwörter: EINGÄNGE / KORRIDORE / SICHERHEIT DER BEWEGUNG / MANAGEMENT FÜR BEWEGUNG

Received: 12.12.2016.

Accepted: 10.04.2017 


\title{
МЕНАЏМЕНТ КРЕТАҢА ПОСЕТИЛАЦА У СПОРТСКОМ ОБЈЕКТУ
}

\author{
Душко Кузовић \\ Источни медитерански универзитет, Архитектонски факултет, Кипар
}

\begin{abstract}
Сажетак
Менаџмент кретања посетилаца у објекту је од велике важности за успешну организацију спортског догађаја. Од улаза посетиоца на парцелу спортског објекта до његовог места на трибинама морају бити дефинисани коридори. У зависности од положаја, коридор се додатно дели на логичне зоне: зона између границе парцеле и објекта, спољашња зона, унутрашња зона, зона гледалишта. Прецизном спецификацијом потреба унутар зоне једноставно се организује безбедно и ефикасно кретање посетилаца. Комуникације могу бити хоризонталне и вертикалне. Свака од група има прописана правила обликовања и одржавања. У зависности од техничког решења које је примењено, улази имају дефинисан капацитет и о томе се мора водити рачуна приликом организације спортског догађаја. Поред улаза за посетиоце, постоји велик број улаза намењених специфичним групама као што су такмичари, ВИП, обезбеђење, сервис, медицинска помоћ, медији, особе са посебним потребама, итд. Менаџмент кретања корисника у објекту мора бити предмет пажљиве анализе јер има велику важност за општи утисак о квалитету спортског објекта.
\end{abstract}

Кључне речи: УЛАЗИ / КОРИДОРИ / БЕЗБЕДНОСТ / КРЕТАҢА

\section{УВОД}

Управљање кретања посетилаца у објекту је од велике важности за успешну организацију спортског догађаја. Ради успешне организације кретања од улаза на парцелу спортског објекта до места посетилаца на трибинама, морају се дефинисати прецизно обликовани коридори.

Зонирање је такође од велике важности јер се потребе корисника мењају у зависности од карактеристичне зоне коридора у којој се налази. Стога се коридори могу додатно поделити у зависности од положаја у односу на улаз и трибине, у логичном редоследу: зона између границе парцеле и објекта, спољашња зона, унутрашња зона, зона гледалишта. Прецизном поделом карактеристичних зона кретања посетилаца и спецификацијом потреба унутар зоне важно је за организовање безбедног и ефикасног кретања ка и од места на трибинама (Mitrović, 1983; Ilić, 1998).
Комуникације и улази у објекат су једнако важна места на путу посетилаца ка своме месту на трибинама. Менаџмент кретања корисника у објекту мора бити предмет свакодневне анализе и пажљивог одржавања, имајући у виду важност ефикасног кретања корисника за општи утисак о квалитету спортског објекта (Department for Culture, Media and Sport, 2008)

Циљ рада је да се анализира кретање корисника од улаза на парцелу објекта до његовог места на трибинама, дефинисање елмената коридора, анализа појединих зона у оквиру коридора, „специфицирање“ услова за обликовање и одржавање линија кретања у спортском објекту. Може се очекивати да ће рад допринети бољем познавању питања обликовања и одржавања линија кретања посетилаца у спортском објекту, и бољем управљањем кретања посетилаца. 


\section{КРЕТАҢЕ ГЛЕДАЛАЦА У ОБЈЕКТУ}

Основна два принципа којима се управља кретање посетилаца у спортском објекту могу се дефинисати потребом за безбедношћу и потребом за комфором у кретању (Geraint, Sheard, \&

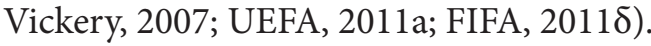

\section{Безбедност}

Под појмом безбедности, може се именовати потреба да се избегне појава панике, безбедност од вандализма, насилничког понашања, повреде, пожара, терористичког напада, било које врсте акцидента итд. Обликовањем спортски објекат мора бити тако решен да предупреди све горе наведене последице (FIFA, 2004; OECD, 2011).

\section{Комфор у кретању}

Под овим појмом подразумева се једноставност, лакоћа, кретање без превеликог физичког и менталног напора, одсуство осећаја изгубљености, са јасним усмерењима. При томе сви елементи обејкта који служе кретању посетилаца, као што су рампе, степенице и лифтови, морају испуњавати све прописима предвиђене захтеве.

\section{ЗОНИРАњЕ СПОРТСКОГ ОБЈЕКТА}

Целокупан спортски објекат према врсти догађаја може се поделити у неколико зона:

- зону спортског терена,

- зону гледалишта,

- зону унутрашње комуникације,

- зону спољашње комуникације, и

- зона између спортског објекта и границе парцеле.

Поменуте зоне постоје и у малим и у великим спортским објектима. Свака од поменутих зона је даље подељена на подцелине које су настале као захтев наметнут из праксе. На пример гледалиште се дели према зонама резервисаним за навијаче два спортска клуба, или у оквиру поменуте зоне према различитим категоријама седења. Преграде између појединих зона у пракси су елементи као што су ограде, зидови или денивелације (Ortner, 1956; Geraint, Sheard, \& Vickery, 2007; Russ, 2009).

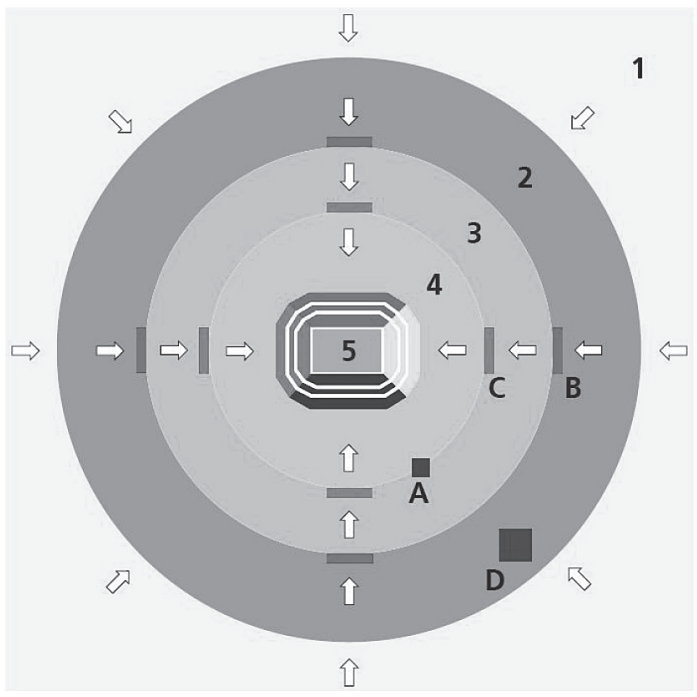

Слика 1. Зоне фудठалског стадиона током ФИФА догађаја: 1. јавна зона, 2. екслузивна зона спортског објекта, 3. спољњи периметар (визуелна контрола карата), 4. унутрашњи периметар (електронска контрола приступа), 5. Штандови: A.Ticketing clearing point; Б. магазини; Ц. обртни крст;

Д. стадионски центар за карте (прилагођено FIFA 2011a).

\section{УЛАЗИ У СПОРТСКИ ОБЈЕКАТ}

Улази у спортски објекат су распоређени према потребама корисника тако да најбезбедније и најефикасније стигну од улаза у објекат до одредишта према коме су се упутили. Улази се могу груписати према врсти корисника на следећи начин:

- улази у гледалиште,

- улази у VIP просторе,

- улази у сервисне просторије,

- улази за спортисте,

- улази за обезбеђење и полицију,

- улази за медицинску помоћ, и

- резервни улази за потребе евакуације из стадиона у случају акцидента.

Треба јасно дефинисати улазе од излаза, мешовито коришћење није порепоручљиво. Сви сервиси на које се наслањају улази морају имати безбедну удаљеност од улаза. На једну капију улаза обично се рачуна да безбедно може да користи до 4000 гледалаца на сат (уколико је отворена) или 500 до 750 гледаца, уколико су обртне (UEFA, 2011a; UEFA, 2011反; UEFA, 2011в).

\section{Положај улаза у односу на објекат}

Улаз мора бити усклађен са унутрашњим и спољашњим комуникацијама. При томе простор ис- 
пред и иза улаза мора да испуни неколико услове. Улази морају бити распоређени довољно често да би се избегла загушења, треба да постоје различити улази за навијаче супарничких екипа, а блиске улазе је могуће груписати ради лакшег управљања групама посетилаца, али само ако су за коришћење исте навијачке групе или исте врсте корисника. Приватни улази су намењени играчима, VIP посетиоцима, директорима, спонзорима и медијима и треба да се налазе близу паркинга резервисаног за њих. Такође, потребно је обликовати улазе тако да могу бити кориштени и за потребе лица са посебним потребама (инвалидитетом, слабовидих, у колицима итд.). Излази за случај опасности се налазе у периметарској огради и могу бити отворени само у изузетним случајевима. Евакуациони излази служе да се спортски објекат испразни у неколико минута, мада се може пунити и неколико сати. Препоручена минимална ширина улаза je 120 цм (Gallant, 2008; Geraint, Sheard, \& Vickery, 2007; UEFA, 2011反).

\section{Контрола улаза}

Од места уласка у спортски објекат до места у гледалишту, кориснику спортског објекта потребно је да прође једну или неколико провера. Циљ провера је контрола карата, али и друге врсте контрола усмерених на безбедност корисника. Прва контрола је на самом улазу и подразумева поред контроле карата и безбедоносну проверу. Друга контрола је мање формална и претежно је посвећена безбедносним мерама. Трећа контрола има безбедоносну функцију и обавља се на местима где се одвајају посебне групе гледалаца. На сваком од наведених места треба да буде обезбеђено довољно простора како би се избегла загушења и гужве; барови и ресторани морају бити удаљени на безбедну дистанцу.

\section{Јасноћа и једноставност праваца кретања}

Због кретања у групи приликом уласка и изласка, јасноћа обавештења о правцима кретања је неопходна. Нарочито код великих спортских објеката, потребно је кроз правилну и јасну сигнализацију уливати сигурност гледаоцима. Стога је потребно применити неколико решења:

a) број избора пред којим се суочава гледалац на путу до свог седишта увек треба да буде што мањи (препоручено два),

б) сви знаци и ознаке морају имати видљивост из најнеповољнијих делова коридора којим се креће корисник,

в) знаци морају бити јасни и читљиви.

Посетиоци морају да имају највише две правца која бирају (од којих је један прави). Уколико се гледалац креће у гомили, која се креће брзо, а гледалац се налази под притиском, број одлука које може да донесе се смањује, а време потребно за њихово доношење продужава. Поред визуелних знакова потребно је организовати службу асистенције. (Smith, 1996; UEFA, 2011б; Geraint,

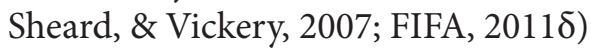

Правац кретања посетилаца према сигурносној зони

Слика 2. Троугаоне, бочно формиране, површне за привремено застајање посетилаца ради сагледавања даљег кретања без блокирања тока на коридору којим се крећу (прилагођено Geraint, Sheard, \& Vickery, 2007)

\section{Понашање гледалаца од улаза до седишта}

Спроведена истраживања су дефинисала главне дилеме и питања која гледалац себи поставља на путу од улаза у објекат до свог седишта. Знакови и упутства који се налазе на спортском објекту морају да одговоре на његова питања на најефикаснији начин. Уобичајена питања гледао- ца на путу од улаза у објекат до свог седишта су: (Gallant, 2008)

1. Да ли сам домаћи или гостујући навијач?

2. Да ли имам карту за стајање или седење?

3. Да ли сам са седиштем у гоњој или доњој зони?

4. Да ли сам у плавој или црвеној секцији? 
5. Да ли је број мог седишта од 1 до 10 или од 11 до 20?

6. Где је моје седиште у овом делу реда?

\section{Јасна видљивост}

У обликовању комуникација у спортском објекту јасноћа је први и основни задатак. На коридору нема простора за драматичне игре светла и таме, познатог и непознатог, какве се користе у другим областима архитектуре. Све визуре током коридора којим се креће гледалац морају бити јасне и дуге како би се лако и брзо могао орјентисати. Јасна видљивост је посебно значајна у случају акцидента када је гледалац у групи, под притиском кретања групе и смањене концентрације. Промене нивоа морају бити добро осмишљене и планиране како не би дошло до нагомилавања гледалаца пре степеништа.

\section{Јасан система знакова}

Систем знакова не служи само да би описао зграду и буде пасиван систем знакова који декоришу објекат. Његова првенствена улога је да одговара на питања која гледалац поставља себи како би што пре и једноставније дошао до места за које је купио карту. При томе треба водити рачуна о низу елемената који помажу да се место поруке идентификује а порука која се налази на њему што пре уочи, разуме, и поступи по њој или не. У том послу помаже разумевање људског вида, видног поља, основне боје табле на којој се налази знак, боје знака, врсте и величине фонта, контраста табле у односу на подлогу, осветљености итд. То је посао за високо специјализоване стручњаке.

\section{Безбедне површине у коридору}

Површине које се налазе са стране траке за кретање и служе да посетиоци могу у њима да застану, а да при томе не задржавају кретање основне групе.

\section{Услужни простори.}

Препорука је да киосци, ठарови, кафеи, центри за чување деце морају бити најмање 6 метара удаљени од излаза или улаза у зону спортског објекта у којој се налазе (Rick, Langston, \& de Valence, 2003; McGregor \& Shiem-Shin, 2003).

\section{ИЗЛАЗ ПОСЕТИЛАЦА ИЗ ОБЈЕКТА}

Траса изласка из објекта пожељно је да прати трасу уласка у објекат. Све препоруке које су важиле за одређивање и распоред улаза у објекат важе и за трасу према излазу из објекта. Све операције које обавља посетилац при уласку обавља и приликом изласка из објекта. Питања која је гледалац постављао од улаза до свог седишта, поново поставља само обрнутим редом.

Потребне су две врсте излаза посетилаца из објекта: редовни и ванредни. Редован излаз није потребно визуелно образлагати. Ванредан излаз је у случају акцидента и он се мора обавити у дефинисаном временском року. И код редовног излаза и код ванредног излаза потребно је увек вршити анализу времена изласка посетилаца из објекта. Према истраживањима и искуству, гледалац уколико нема сметњи приликом кретања, може да пређе за 60 секунди: на равном или благом терену 150 метара, а на степеништу 30 метара. При томе је размак између физичких лица на равном 2.5 метара, а на степеништу 0.75 метара.

\section{ПРЕПОРУКЕ ЗА ОБЛИКВОАЊЕ КОРИДОРА ЗА КРЕТАҢЕ ПОСЕТИЛАЦА}

\section{Капије и врата са обртним крстом}

Врата су најјевтиније и најбрже решење за улазе у објекат. Могу да пропусте око 4000 гледалаца на сат. Имају недостатак да су недовољно софистицирана за безбедносне провере.

Врата са окретним крстом су боље безбедносно решење, али њихов капацитет је од 500 до 750 посетилаца на сат. Искуства из праксе говоре, да је реалан просечан број гледалаца, који могу да безбедно прођу кроз овакву врсту капије, 660 на сат. Уколико се трибине морају напунити за краће време, потребно је обезбедити већи број оваквих улаза.

Улази на трибине могу да имају бројач посетилаца, што помаже безбедности у спортском објекту. Контрола карата је прецизнија јер, уколико су тикети кодирани и гласе на име, могу се рачунарски лако идентификовати сви присутни у објекту, чиме се обесхрабрује неконтролисан упад у објекат. Такође, ради спречавања нагомилавања посетилаца испред улаза, продаја улазница мора бити најмање 10 метра удаљена од улаза. 
Недостаци оваквих улаза су: проблеми са одржавањем хигијене пода испод врата и могућност повређивања гледалаца у случају неконтролисаног приступа. На улазу у објекат се обично поставља „серпентинска ограда“ која служи да се обезбеди контрола над масом приликом приступа.

\section{Хоризонтална кретања на коридору}

Улаз у спортски објекат пре догађаја може да траје и до три часа, док излаз из објекта мора бити у року од неколико десетина минута. У спортском објекту се мора дефинисати „пешачки цевовод“ који води од улаза до пролаза ка седишту и назад и треба направити његову детаљну анализу (UEFA, $2011 \mathrm{a}, \delta, \mathrm{B})$.

Правилна процена кретања корисника кроз спортски објекат је веома важна за обликовање и контролу коридора кретања. У основи заснива се на неколико елемената:

1. Улази. Ширина и тип улаза одређују број посетилаца који могу да уђу у објекат у јединици времена. Жељени период пуњења и пражњења објекта одређује број улаза.

2. Излази. Врата се морају отварати у правцу кретања посетилаца односно напоље. Они могу да приме 40 до 60 посетилаца у минути по јединици ширине (60 цм). Према овом искуству се одређује број излаза у односу на жељено време излаза.

3. Хоgници и иролази. Ширина њихова је дефинисана прописима и мењају се током времена.

4. Обласиии йојеgиначної зайушења. То су додатне површине на постојеће коридоре за кретање и служе да се поједини посетиоци одморе, а да не задржавају кретање у коридору.

\section{Вертикална кретања на коридору}

Ова врста кретања (степенице и рампе) је неопходна, али се мора користити у што мањој мери. Брзина кретања групе на вертикалним трасама је знатно мања него код хоризонталног кретања, а загушења су чешћа.

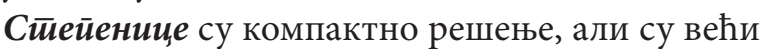
извор опасности, него косе рампе. Препорука је да се планирају у паровима, а највећи нагиб који је дозвољен је $33^{\circ}$. Приликом одређивања нагиба првенствену улогу има однос висине и ширине степеника. Рукохвати и површинска обрада степеника су веома важни, треба да спрече клизање, али и да су једноставни за одржавање.
Косе рамйе имају предност, једноставније су за кретање од степеница, и у случају пада, последице повређивања су мање опасне, него код степеница. Уколико су пројектоване и грађене да имају одговарајућу ширину и конструктивно могу да поднесу терет, могу да се користе за кретање возила. Према форми могу бити кружне или праволинијске. Рукохвати и завршна обрада морају бити усклађени са начином коришћења.

Ескалайори. Због велике цене и трошкова експлоатације веома ретко се користе на спортским објектима.

Лифйови. Појединачно су малог капацитета и могу бити извор опасности у случају губљења контроле над кретањем посетилаца. У пракси се користе се за VIP, приватне, клупске и извршне делове гледалишта, особље, обезбеђење, полициjу, хитну помоћ, медије, особе са посебним потребама итд.

\section{ЗАКЉУЧАК}

Управљање кретања посетилаца у објекту је од велике важности за успешну организацију спортског догађаја. Стога се од улаза на парцелу спортског објекта до места посетилаца на трибинама морају дефинисати коридори. У зависности од положаја, карактеристичне зоне коридора се нижу у логичном редоследу: зона између границе парцеле и објекта, спољашња зона, унутрашња зона, зона гледалишта. Прецизном поделом карактеристичних зона кретања посетилаца и спецификацијом потреба унутар зоне, једноставно је организовати безбедно и ефикасно кретање ка и од места на трибинама. Комуникације се могу груписати према нагибу површине на хоризонталне и вертикалне. Свака од наведене две групе има дефинисана правила обликовања и одржавања. Улази у објекат су једнако важна места на путу посетиоца ка свом месту на трибинама. У зависности од техничког решења које је примењено имају дефинсан капацитет и о томе се мора водити рачуна приликом пројектовања објекта, али и организације спортског догађаја. Поред улаза за посетиоце, постоји велик број улаза намењених специфичним групама у објекту као што су такмичари, ВИП, обезбеђење, сервис, медицинска помоћ, особе са посебним потребама, медији итд. Менаџмент кретања корисника у објекту мора 
бити предмет свакодневне анализе и пажљивог одржавања имајући у виду важност ефикасности кретања корисника за општи утисак о квалитету спортског објекта.

\title{
ЛИТЕРАТУРА
}

1. Gallant, B. (2008). The facility manager's guide to environmental health and safety. Lanham: Government Institutes.

2. Geraint, J., Sheard, R., \& Vickery, B. (2007). STADIA: A Design and Development Guide. Oxford: Elsevier.

3. Department for Culture, Media and Sport (2008). Guide to Safety at Sports Grounds. London.

4. Илић, С. (1998). Сӣорйски објекӣu. Београд: СИА

5. McGregor, W., \& Shiem-shin Then, D. (2003). Facilities Management and the Business of Space. Oxford: Butterworth-Heinemann.

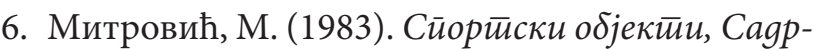
жај и обележја иіре и сйорй а у сйамбеној среgини и насељу. Београд: Архитектонски факултет.

7. OECD (2011). Preventing and Reducing Armed Violence in Urban Areas: Programming Note, Conflict and Fragility. OECD Publishing.
8. Ortner, R. (1956). Sportbauten, Anlage-Bau-Ausstatug. München: Calwey.

9. Rick, B., Langston, C., \& de Valence, G. (2003). Workplace strategies and facilities management. New York: Taylor \& Francis.

10. Russ, T. (2009). Site Planning and Design Handbook, McGraw-Hill.

11. Smith, M. (1996). Interiors Management: A Guide for Facility Managers, The Fairmont Press.

12. UEFA (2011a). Access For All, Genève.

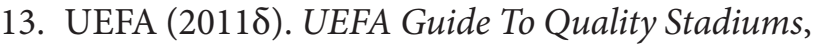
Genève.

14. UEFA (2011в). UEFA Stadium Infrastructure Regulations, Genève.

15. FIFA (2004). Safety Regulations. Zurich.

16. FIFA (2011a). FIFA Stadium Safety and Security Regulations. Zurich.

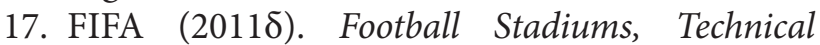
Recommendations and Requirements. Zurich.

\section{MANAGEMENT DER BEWEGUNG VON BESUCHERN IN SPORTOBJEKTEN}

\begin{abstract}
Zusammenfassung
Das Management der Bewegung von Besuchern in einem Objekt ist von großer Bedeutung für die erfolgreiche Organisierung eines Sportevents. Vom Eintritt der des Besuchers auf die Parzelle des Sportobjekts bis zu seinem Platz auf den Tribünen müssen die Korridore definiert sein. In Abhängigkeit von der Position wird der Korridor zusätzlich in logische Zonen eingeteilt: Zone zwischen der Grenze der Parzelle und des Objekts, äußere Zone, innere Zone, Zuschauerzone. Durch präzise Spezifizierung der Bedürfnisse innerhalb einer Zone wird auf einfache Weise eine sichere und effiziente Bewegung der Besucher organisiert. Die Kommunikationen können horizontal und vertikal sein. Jede der Gruppen hat vorgeschriebene Regeln für Gestaltung und Instandhaltung. In Abhängigkeit von der angewendeten technischen Lösung haben die Eingänge eine definierte Kapazität und dies muss bei der Organisierung eines Sportevents beachtet werden. Neben den Besuchereingängen gibt es noch eine große Anzahl an Eingängen, die für spezifische Gruppen bestimmt sind, wie zum Wetteiferer, VIP, Sicherheitsdienst, Service, ärztliche Hilfe, Medien, Personen mit besonderen Bedürfnissen usw. Das Management der Bewegung von Besuchern in einem Objekt muss Gegenstand einer sorgfältigen Analyse sein, weil es eine große Bedeutung für den allgemeinen Eindruck über die Qualität eines Sportobjekts trägt.
\end{abstract}

Schlüsselwörter: EINGÄNGE / KORRIDORE / SICHERHEIT DER BEWEGUNG / MANAGEMENT FÜR BEWEGUNG

Примљен: 22.12.2016.

Прихваћен: 10.04.2017. 